\title{
IMPLIKASI MARKET VALUE, VARIAN RETURN, LABA PER SAHAM DAN DEVIDEN TERHADAP BID-ASK SPREAD SAHAM SYARIAH
}

\author{
Fitriyah \\ Fakultas Ekonomi UIN Maliki Malang \\ Jln. Gajayana 50 Malang \\ E-mail: urannia_uin@yahoo.com/ HP.: 08123355720
}

\begin{abstract}
This research was aimed to determine whether the variables variance return, market value, dividend and earning per share influence the bid-ask spread partially and simultaneously of shares of sharia in Indonesia Stock Exchange. The population in this research are the companies listed in the Jakarta Islamic Index over the period 2007 to 2010. Sampling using a purposive sampling technique and number of sample are 10 companies. The result shows, the variance return, market value, dividend and earning per share simultaneously influence the bidask spread. While partially, there ar three variables that significantly influence the bid-ask spread that is variance return with significant positif, dividend, and erningper share with a significant negative relationship. Variable market value does not affect the bid ask spread. Increase in variance return would cause the dealer / broker to cover the high spread. The existence of dividend payments and earnings per share would have an impact on high stock trading so dealers will not take long to save the stock This results in reduced inventory holding cost and ultimately lower the bid ask spread.
\end{abstract}

Key word: varian return, market value, bid ask spread

Pasar modal memegang peranan penting di dalam perekonomian. Pasar modal pada dasarnya bertujuan untuk menjembatani aliran dana dari investor yaitu pihak yang memiliki dana, dengan issuer yakni pihak yang membutuhkan dana. Investor di pasar modal hanya menyediakan dana tanpa harus terlibat langsung dalam aktiva riil yang diperlukan untuk investasi. Investor akan memperoleh imbalan (return) sesuai dengan karakteristik investasi yang dipilih. Investor saham akan memperoleh keuntungan dari perubahan harga saham dan dividen. Selain return, seorang investor

Dalam membeli dan menahan kepemilikan saham, sinvestor tidak hanya mengharapkan return yang maksimal, namun juga harus mempertimbangkan risiko (risk). Investor akan menanamkan modalnya pada saham-saham perusahaan yang memiliki return lebih dari perusahaan lain dengan risiko yang sama atau 
tingkat keuntungan yang sama dengan risiko yang lebih kecil. Untuk dapat melakukan investasi dengan tepat maka seorang investor saham perlu memiliki sejumlah informasi yang berkaitan dengan pergerakan harga saham agar bisa mengambil keputusan tentang saham perusahaan yang layak untuk dipilih. Penilaian saham yang menyeluruh, bisa meminimalkan risiko sekaligus membantu investor mendapatkan keuntungan yang wajar. Pada umumnya investasi yang menghasilkan return yang tinggi berbanding lurus dengan risikoartinya peluang risiko yang terjadi juga semakin besar.

Di pasar modal, investor dihadapkan pada kondisi ketidakseimbangan informasi atau asimetri informasi, dimana sebagian pelaku pasar /partisan memiliki informasi yang lebih superior dibandingkan dengan pelaku pasar yang lainnya. Besar kecilnya spread menunjukkan seberapa besar informasi asimetri diantara pelaku pasar. Untuk mengurangi tingkat asimetri infomasi tersebut makan pelaku pasar berupaya mendapatkan sinyal tertentu yang dapat dijadikan sebagai informasi untuk mengurangi ketidakpastian yang terjadi. Usaha ini akan menimbulkan biaya informasi. Brokerldealer berusaha menentukan spread yang cukup untuk menutup biaya kepemilikan sekuritas, biaya pemrosesan pesanan dan biaya informasi (Krinsky dan Lee (1996) dalam Purwanto (2003).

Bid-ask spread merupakan selisih antara beli (bid) dengan jual (ask). Bid price adalah harga tertinggi yang ditawarkan oleh dealer atau harga dimana spesialis atau dealer menawar untuk membeli saham, sedangkan ask price adalah harga terendah dimana dealer bersedia untuk menjual saham. Krinsky dan Lee (1996) menyatakan bahwa terdapat tiga komponen biaya di dalam menetapkan bis-ask spreaad, yaitu biaya pemrosesan pesanan (order processing cost), biaya pemilikan sekuritas (inventory holding cost), dan Adverse information cost.

Biaya pemrosesan pesanan merupakan biaya yang dikeluarkan untuk mengatur transaksi, mencatat serta melakukan pembukuan. Biaya pemilikan sekuritas terdiri dari risiko harga dan opportunity cost yang dihubungkan dengan pemilikan saham. Sedangkan biaya informasi adalah biaya yang timbul karena adanya informasi asimetri para pelaku pasar modal. Informasi asimetri timbul karena adanya informasi yang tidak dapat didistribusikan secara merata kepada semua pelaku di pasar modal atau dengan kata lain, biaya adverse information 
muncul ketika broker/dealer melakukan transaksi dengan investor yng memiliki informasi yang superior. Sehingga dapat disimpulkan bahwa besarnya ketidakseimbangan informasi yang dihadapi dealer akan ter-cermin pada spread.

Ada beberapa faktor yang diidentifikasi sebagai determinan bid ask spread yakni harga, volume perdagangan, dan varian return (Stoll dalam Purwanto (2003). Harga diidentifikasi berpengaruh negatif terhadap bid ask spread. Harga yang memberikan return yang tinggi mengindikasikan bahwa saham tersebut disukai oleh investor, sehingga broker/dealer (perantara pedagang efek) tidak perlu memegang saham tersebut terlalu lama sehingga menurunkan biaya pemilikan saham yang berarti mempersempit bid ask spread saham tersebut.

Volume perdagangan diidentifikasi berpengaruh terhadap bid ask spread. Volume perdagangan saham yang besar menandakan bahwa saham aktif ditransaksikan, sehingga broker/dealer tidak perlu menyimpan saham tersebut dalam waktu yang lama. Hal ini berdampak pada bid ask spread saham tersebut rendah. Varian return dianggap berpengaruh positif terhadap bid ask spread. Pada volatilitas harga saham yang tinggi, investor yang memiliki informasi privat akan berpeluang untuk memperoleh keuntungan. Hal ini akan menyebabkan broker/dealer akan memperbesar keuntungan sebagai kompensasi atas risiko kerugian dengan meningkatkan spread. Variabilitas return saham mewakili risiko yang dihadapi broker/dealer, semakin besar risiko suatu saham maka broker/dealer akan menutupinya dengan spread yang lebih besar.

Dari latar belakang diatas, penelitian ini menguji kembali konsistensi penelitian sebelumnya terhadap variabel market value, varian return, laba per saham dan deviden serta pengaruhnya secara partial dan simultan terhadap bid ask spread saham syariah di Bursa Efek Indonesia. Perbedaan penelitian ini dengan penelitian sebelumnya adalah pada sampel penelitian dan variabel independen yang digunakan. Pada penelitian sebelumnya umumnya menggunakan sampel saham biasa (konvensional) di Bursa Efek Indonesia. Namun dalam penelitian ini menggunakan saham syariah yang memiliki karekteristik yaitu harus memenuhi prinsip-prinsip dasar syariah yang berbeda dengan saham konvensional, Sedangkan dari variabel yang diteliti, peneliti memproksikan variabel harga saham dan volume perdagangan dengan market value. Karena 
market value merupakan ukuran perusahaan yang diperoleh dari harga saham dikalikn dengan volume perdagangan saham. Disamping itu, dalam penelitian ini menambahkn variabel laba per saham dan deviden yang merupakan faktor yang membuat seorang investor melakukan investasi saham.

\section{Bid Ask Spread}

Bid price adalah harga tertinggi yang ditawarkan investor yang akan membeli suatu saham, sedangkan ask price adalah harga terendah yang ditawarkan investor yang akan menjul suatu saham. Menurut Jones (2002) spread merupakan selisih antara harga beli (bid) tertinggi yang menyebabkan investor bersedia untuk membeli saham tertentu dengn harga jual (ask) terendah yang menyebabkan investor bersedia menjual sahamnya. Corrado dan Jordan (2000) mengemukakan bahwa bid-ask spread merupakan ukuran laba kotor yang diinginkan dealer dari suatu transaksi pembelian pada bid price dan penjualan pada ask price. Bid-ask spread dari dealer (broker) kemudian diturunkan kepada investor, artinya biaya dan tingkat kompensasi yang diinginkan oleh dealer sebagai perantara perdagangan di bursa efek dibebankan kepada investor selaku nasabah dealer.

Hamilton dalam Purwanto (2003) menjelaksan bahwa spread mempunyai dua model yaitu: 1) Dealer spread adalah selisih antara harga bid dan harga ask yang menyebabkan dealer ingin memperdagangkan sekuritas dengan aktivanya sendiri untuk mendapatkan keuntungan sendiri; 2). Market spread merupakan perbedaan antara permintaan beli tertinggi dengan penawaran jual terendah yang terjadi pada suatu saat tertentu. Spread tidak terlepas dari aktivitas yang dilakukan oleh pihak-pihak tertentu yang dapat mempengaharui besarnya transaksi sekuritas di lantai bursa, salah satunya adalah Pedagang Perantara Efek (PPE) yang berfungsi sebagai dealer, penasehat investasi dan broker. Dealer spread akan dapat diamati dalam mekanisme perdagangan di bursa paralel (misalnya NASDAQ) karena dealer di bursa paralel hanya berprofesi sebagai dealer tidak sebagai broker. Di Bursa Efek Indonesia terdapat kesulitan mengamati dealer spread karena fungsi perantara pedagang efek yang berperan ganda yaitu sebagai dealer dan broker atau biasa disebut broker/dealer. Oleh karena itu, penelitian ini 
menggunakan market spread karena dealer spread tidak dapat diamati di Bursa Efek Indonesia.

\section{Variance Return}

Variance return menunjukkan variabilitas return di seputar return normal yang diakibatkan adanya volatilitas (fluktuasi harga) saham. Semakin tinggi variance return menunjukkan semakin bervariasinya return harian yang diperoleh investor. Hal ini mencerminkan ketidakpastian (resiko) pasar yang tinggi. . Risiko saham yang semakin tinggi menyebabkan dealer berusaha menutupinya dengan spread yang lebih besar.

Dalam kaitannya dengan pertimbangan investasi khususnya keputusan untuk menahan atau melepas suatu kepemilikan saham, return dan tingkat resiko merupakan bahan pertimbangan tambahan yang dapat digunakan dalam pengambilan keputusan karena pada dasarnya antara tingkat resiko yang harus ditanggung dengan penentuan waktu untuk keputusan menahan atau melepas saham merupakan suatu hal yang berkaitan. Argumen ini didukung oleh hasil penelitian Branch dan Feed (1977) dan Stoll (1978) yang menunjukkan bahwa varian saham berhubungan positif dengan bid ask spread.

\section{Market Value}

Nilai pasar saham merupakan harga saham yang terjadi di pasar bursa pada saat tertentu akibat aktivitas transaksi di pasar bursa (mekanisme pasar). Nilai pasar saham ini merupakan cerminan besarnya ukuran perusahaan yang dihitung dengan mengkalikan jumlah saham beredar dengan harga pasar saham. Besarnya ukuran perusahaan mempunyai hubungan negatif dengan beta saham (risiko pasar saham), yaitu tingkat risiko portofolio relatif terhadap risiko pasar. Investor menganggap perusahaan besar memiliki risiko lebih kecil dibandingkan dengan perusahaan kecil, karena perusahaan besar dianggap lebih mempunyai akses ke pasar modal (Jogiyanto, 2002). Pada penelitian sebelumnya variabel yang berpengaruh terhadap bid sk spread adalah volume perdagangan dan harga saham. Namun dalam penelitian ini kedua variabel tersebut diproksikan dengan market value. 
Spread berhubungan terbalik dengan jumlah aktivitas perdagangan saham. Saham yang lebih banyak aktivitas perdagangannya cenderung memiliki spread yang rendah. Hubungan yang terbalik antar jumlah aktivitas perdagangan (atau nilai pasar) dan ukuran spread dapat dijelaskan dengan segera setelah diketahui bahwa spread yang ada adalah kompensasi bagi dealer yang memberikan investor likuiditas. Semakin kecil jumlah perdagangan, semakin jarang dealer akan memperoleh spread. Jadi dealer akan memerlukan spread yang memadai bagi sekuritas yang lebih sering diperdagangkan. (Sharpe, 2005)

Volume perdagangan diartikan sebagai jumlah lembar saham yang diperdagangkan pada hari tertentu (Abdul dan Nasuhi, 2000). Perdagangan suatu saham yang aktif, yaitu dengan volume perdagangan yang besar, menunjukkan bahwa saham tersebut digemari oleh para investor yang berarti saham tersebut cepat diperdagangkan. Ada kemungkinkan dealer akan mengubah posisi kepemilikan sahamnya pada saat perdagangan saham semakin tinggi atau dealer tidak perlu memegang saham dalam jumlah terlalu lama. Volume perdagangan akan menurunkan biaya pemilikan saham sehingga menurunkan spread. Dengan demikian semakin aktif perdagangan suatu saham atau semakin besar volume perdagangan suatu saham, maka semakin rendah biaya pemilikan saham tersebut yang berarti akan mem-persempit bid-ask spread saham tersebut.

Harga saham yang senantiasa memberikan return yang tinggi mengindikasikan bahwa saham tersebut disukai oleh investor, sehingga broker/dealer (perantara pedagang efek) tidak perlu memegang saham tersebut terlalu lama sehingga menurunkan biaya pemilikan saham yang berarti mempersempit bid ask spread saham tersebut.

\section{Deviden}

Dividen merupakan bagian dari keuntungan perusahaan yang didistribusikan kepada para pemegang saham dan pada umumnya dilakukan secara berkala baik (enam bulanan atau satu tahun sekali) dalam bentuk cash atau lainnya, misalnya dividen saham (stock dividend) dan dividen extra (extra dividend). Kebijakan pembagian dividen atau laba akan ditahan dalam bentuk laba ditahan guna investasi di masa datang adalah merupakan keputusan menajemen. Dalam kebijakan dividen bukan hanya menentukan besarnya dividen yang akan 
dibagikan, tetapi juga mencakup apa bentuk dividen yang akan dibayarkan. Alternatif bentuk pembayaran dividen, yaitu dividen tunai, dividen yang berupa saham(stock dividend), pemecahan saham (stock splits), dan pembelian kembali saham.

Teori sinyal-sinyal dividen (Miller dan Rock, 1985) menyatakan bahwa dividen menyampaikan informasi tentang ekspektasi-ekspektasi manajer dengan memperhatikan arus kas perusahaan, maka informasi yang dikandung dividen mengurangi informasi asimetris. Regularitas perusahaan dalam mempublikasikan pembayaran dividen-dividennya menunjukkan arus informasi yang periodik, meskipun dilakukan dalam kuantitas dan kualitas yang berbeda. Karena itulah, informasi yang terkandung dalam kebijakan dividen akan menghasilkan informasi asimetris di tingkat yang lebih rendah daripada tidak membayarkan dividen.

Para supplier/pemasok dana juga tidak akan menyediakan dana kecuali mereka menerima informasi tentang kegunaan yang diajukan untuk dana-dana tersebut. Para pemegang saham juga menerima informasi baru. Informasi ini disediakan untuk pelaku pasar, mengurangi derajat keasimetrisan dan sebagai konsekuensinya, mempengaruhi bid-ask spread yang lebih rendah. Rozeff (1982) dalam Maulina (2010).

Selain itu pembayaran dividen terkait juga dengan risiko. Bila pembayaran dividen yang dilkukan oleh perusahaan meningkt maka risiko yang ditanggung oleh investor akan menurun (Beaver et al., 1970 dan Rozeff, 1982 dalam Ryan, 1996). Oleh karena itu, jika pembayaran dividen meningkat, harga saham akan meningkat pula. Ini akan mengurangi risiko perusahaan dan mengakibatkan penurunan bid ask spread.

\section{Laba Per Saham}

Earning yang tinggi mengindikasikan bahwa saham perusahaan memiliki prospek yang baik, sehingga saham tersebut aktif diperdagangkan. Apabila suatu saham aktif diperdagangakan, maka dealer tidak lama menyimpan saham tersebut sebelum diperdagangkan. Hal ini akan mengakibatkan menurunnya biaya pemilikan saham yang pada akhirnya menurunkan tingkat bid ask spread. Argumen ini didukung oleh hasil penelitian Senteney (2001) dalam Callahan, 
Charles dan Yohn (1997) yang menunjukkan bahwa spread yang lebih kecil meningkat ketika earnings positif daripada ketika earning negatif.

\section{Pengembangan Hipotesis}

Berdasarkan landasan teori dan hasil penelitian terdahulu maka dapat dirumuskan hipotesis sebagai berikut :

H.1 : Diduga varian return mempunyai pengaruh positif signifikan terhadap bid ask spread saham syariah yang tercatat dalam Jakarta Islamic Indeks (JII)

H.2 : Diduga market value mempunyai pengaruh negatif signifikan terhadap bid ask spread saham syariah yang tercatat dalam Jakarta Islamic Indeks (JII)

H.3 : Diduga dividen mempunyai pengaruh positif signifikan terhadap bid ask spread saham syariah yang tercatat dalam Jakarta Islamic Indeks (JII)

H.4 : Diduga laba per saham mempunyai pengaruh negatif signifikan terhadap ask spread saham syariah yang tercatat dalam Jakarta Islamic Indeks (JII)

H5 : Diduga, market value, variance return dividend an laba per saham secara bersama-sama mempunyai pengaruh terhadap bid-ask spread saham syariah yang tercatat dalam Jakarta Islamic Indeks (JII)

\section{METODE}

Penelitian ini menggunakan rancangan penelitian penjelasan (explanatory) yang menjelaskan hubungan kausal antara variabel-variabel penelitian melalui pengujian hipotesis. Sedangkan karakteristik penelitian ini bersifat extended replication yang merupakan pengembangan dari penelitian terdahulu. Populasi dalam penelitian ini meliputi perusahaan yang termasuk dalam Jakarta Islamic Indeks selama periode 2007 sampai dengan 2010. Pengambilan sampel menggunakan teknik purposive sampling yakni teknik penentuan sampel berdasarkan pertimbangan tertentu (Sugiyono,2002). Dasar pertimbangan tersebut adalah: 1) Saham tersebut diperdagangkan secara aktif di Bursa Efek Jakarta selama periode pengamatan yaitu tahun 2007 s/d 2010; 2) Emiten terdaftar di Jakarta Islamic Indeks selama kurun waktu pengamatan yaitu tahun 2007 s/d 2010 dan 3) Emiten membukukan laporan keuangan dan tersedia data harga saham harian, volume perdagangan harian, bid price dan offer price. Jumlah perusahaan 
yang dijadikan sampel penelitian dan memenuhi persyaratan di atas adalah berjumlah 10 perusahaanm sebagai berikut:

Tabel 1. Nama-nama perusahaan

\begin{tabular}{|l|l|}
\hline No & \multicolumn{1}{|c|}{ Nama Perusahaan } \\
\hline 1. & Astra Agro Lestari Tbk (AALI) \\
\hline 2. & Aneka Tambang (Persero) Tbk (ANTM) \\
\hline 3. & International Nickel Indonesia Tbk (INCO) \\
\hline 4. & Indocement Tunggal Prakasa Tbk (INTP) \\
\hline 5. & Kalbe Farma Tbk (KLBF) \\
\hline 6. & Tambang Batubara Bukit Asam Tbk (PTBA) \\
\hline 7. & Semen Gresik (Persero) Tbk (SMGR) \\
\hline 8. & Timah Tbk (TINS) \\
\hline 9. & Telekomunikasi Indonesia Tbk (TLKM) \\
\hline 10. & Unilever Indonesia Tbk (UNVR) \\
\hline
\end{tabular}

\section{Definisi Operasional Variabel}

Selaras dengan perumusan masalah dan hipotesis, maka variabel-variabel yang akan dianalisis dikelompokkan menjadi dua bagian yaitu:

a. Dependent Variable atau Variabel Terikat berupa bid ask price

Spread adalah perbedaan harga tertinggi yang dibayarkan oleh seorang pembeli dengan harga terendah yang bersedia ditawarkan oleh penjual. Konsep perhitungan spread adalah dengan membuat rata-rata bid-ask spread harian untuk tiap jenis saham yang diteliti selama periode observasi. Dengan mengacu pada penelitian Atkins dan Dyl (1997) spread dirumuskan sebagai berikut :

$$
\text { Spread }_{\mathrm{it}}=\left[\sum_{t=1}^{N} \frac{a s k_{i t}-b i d_{i t}}{\left(a s k_{i t}+b i d_{i t}\right) / 2}\right] / \mathrm{N}
$$

Dimana:

Spread $_{\text {it }}$ : rata-rata presentase bid ask spread dari saham $i$, pada tahun $\mathrm{T}$

$\mathrm{N} \quad$ : jumlah pengamatan selama satu tahun

Ask $_{\text {it }} \quad$ : Harga jual terendah yan menyebabkan investor setuju untuk menjual saham $i$ pada hari $t$.

Bid $_{i t} \quad$ : Harga beli terendah yan menyebabkan investor setuju untuk menjual saham $i$ pada hari $t$ 
Data bid dan ask price dapat dilihat di www.idx.co.id. Ask price adalah offer price pada data transaksi harian saham

b. Independent Variable atau Variabel Bebas merupakan variabel yang diduga berpengaruh terhadap variabel terikat, terdiri dari:

1. Variabel X1 : varian return

Variance return adalah tingkat resiko yang terjadi dari suatu kegiatan investasi, terutama akibat transaksi saham di pasar bursa yang disebabkan adanya volatilitas harga saham. Rata-rata Return saham dihitung dengan menggunakan rata-rata aritmatika dari data harian selama periode observasi. (Fabozzi, 2000). Variance return dirumuskan sebagai berikut:

$$
\begin{aligned}
& \mathbf{R}_{\mathbf{i t}}=\left[\frac{\left(P_{t}-P_{t-1}\right)}{P_{t-1}}\right] \\
& \mathbf{R A}=[\mathrm{R} 1+\mathrm{R} 2+\mathrm{R} 3+\ldots+\mathrm{Rm}] / \mathrm{m} \\
& \text { Variance }=\frac{n \sum x^{2}-\left(\sum x\right)^{2}}{n(n-1)}
\end{aligned}
$$

2. Variabel X2: market value

Market value adalah harga saham yang terjadi di pasar pada saat tertentu yang di tentukan oleh pelaku pasar, yaitu merupakan rata-rata harga saham selama satu tahun dikalikan dengan jumlah saham beredar per akhir tahun. Mengacu penelitian Atkin dan Dyl (1997) market value dirumuskan sebagai berikut:

${\operatorname{Mkt~} \operatorname{Val}_{i T}=\left[\sum \text { harga saham }\right.}_{i \mathrm{I}} \mathrm{L}$ x jumlah saham beredar ${ }_{\mathrm{iT}}$

$$
\mathrm{N}
$$

Dimana:

MktValiT : rata-rata market value saham perusahaan i selama semester $\mathrm{T}$ $\mathrm{N} \quad$ : jumlah hari transaksi saham perusahaan i selama semester $\mathrm{T}$ Harga saham $_{\mathrm{iT}}$ : harga penutupan saham perusahaan i pada hari $\mathrm{t}$ Saham beredar ${ }_{\mathrm{iT}}$ : jumlah saham yang beredar pada saham perusahaan i selama semester $\mathrm{T}$

3. Variabel X3 : laba per saham dapat diperoleh dengan membagi laba dengan jumlah saham yang beredar.

4. Variabel X4 : dividen adalah bagian laba yang diberikan emiten kepada para pemegang sahamnya (Widoatmojo :2005) 
Data laba per saham dan dividen dapat diketahui dari Indonesian Capital Market Directory.

\section{Metode Analisis Data}

Pengujian hipotesis menggunakan analisis regresi untuk mengetahui pengaruh antara variabel independen (variance return, market value, laba per saham, dan dividend) terhadap variabel dependen yaitu bid-ask spread. Analisis regresi yang dilakukan dalam pengujian ini adalah model analisis regresi dengan model ordinary least square (OLS) dengan menggunakan SPSS versi 13. Uji t digunakan untuk mengetahui pengaruh parsial dan uji $\mathrm{F}$ digunakan untuk mengetahui pengaruh secara simultan. Sebelum melakukan analisis regresi maka dilakukan uji asumsi klasik yang meliputi uji normalitas, autokorelasi, multikolinearitas dan heterokedastisitas. Adapun model matematis penelitian ini adalah:

$$
Y=\beta_{t}+\beta_{1} X_{1}++\beta_{2} X_{2}+\beta_{3} X_{3}+\beta_{4} X_{4}+e
$$

\section{HASIL DAN PEMBAHASAN}

Uji asumsi klasik dilakukan untuk mengetahui apakah model yang dipakai tersebut relevan atau tidak. Uji normalitas yang dilakukan adalah dengan melihat normal probability plot yang membandingkan distribusi kumulatif dari data sesunggguhnya dengan distribusi kumulatif dari distribusi normal. Gambar dibawah ini menunjukkan bahwa data bergerombol disekitar garis uji yang mengarah ke kanan atas, tidak ada gerombolan plot data yang terletak jauh dari garis uji normalitas. Dengan demikian data tersebut bisa dikatakan mempunyai sebaran yang normal atau dengan kata lain telah memenuhi asumsi normalitas sebaran data.

\section{Gambar P-P Plot}




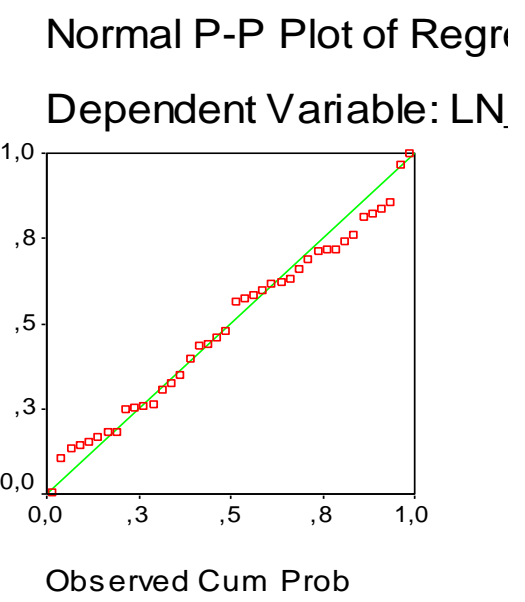

Terdapat cara lain untuk melakukan uji normalitas yaitu dengan melakukan Kolmogorov-Smirnov test. Hasil uji dengan menggunakan normal probability plot dan Kolmogorov-Smirnov test menunjukkan hasil yang normal (diatas signifikansi 5\%) pada data setelah ditransformasikan ke dalam bentuk logaritma natural (Ln).

Tabel 2. Uji One Sample Kolmogorov Smirnov Test terhadap Variabel variabel variance return $(\mathrm{X} 1)$, market value $(\mathrm{X} 2)$, dividen $(\mathrm{X3})$ dan laba per saham (X4)

One-Sam ple Kolm ogor ov-Sm ir nov Te st
\begin{tabular}{|ll|r|r|r|r|r|}
\hline & & LN SPRED & LN V AR & LN MARKT & \multicolumn{1}{c|}{ LN LPS } & LN DEV \\
\hline N & & 40 & 40 & 40 & 40 & 40 \\
Normal Parameters a,b & Mean & $-5,0291$ & $-6,7924$ & 31,2840 & 6,0318 & 5,1989 \\
& Std. Deviation &, 65460 &, 84990 &, 92865 & 1,00296 & 1,39571 \\
Most Extreme & Absolute &, 088 &, 114 &, 135 &, 104 &, 123 \\
Differences & Positive &, 087 &, 114 &, 135 &, 063 &, 123 \\
& Negative &,- 088 &,- 074 &,- 085 &,- 104 &,- 121 \\
Kolmogorov-Smirnov Z & &, 558 &, 722 &, 851 &, 659 &, 780 \\
Asymp. Sig. (2-tailed) & &, 915 &, 674 &, 464 &, 778 &, 577 \\
\hline
\end{tabular}
a. Test dis tribution is Normal.
b. Calc ulated from data.

Cara mendeteksi ada tidaknya multikolinieritas adalah dilihat dari nilai variance inflation factor (VIF). Bi la nilai VIF lebih dari 10 maka terjadi multikolinearitas, dan bila dibawah 10 maka tidak ada masalah dengan multikolinieritas. Hasil dari uji yang dilakukan tidak terdapat nilai VIF di atas 10, sehingga dapat disimpulkan bahwa model regresi pada penelitian ini terbebas dari problem multikolinieritas.

Tabel 3. Uji Multikolinearitas terhadap Variabel -variabel variance return (X1), market value (X2), dividen (X3) dan laba per saham (X4) 
Coefficients

\begin{tabular}{|c|c|c|c|c|c|c|c|c|}
\hline \multirow{2}{*}{\multicolumn{2}{|c|}{ Model }} & \multicolumn{2}{|c|}{$\begin{array}{c}\text { Unstandardized } \\
\text { Coefficients }\end{array}$} & \multirow{2}{*}{$\begin{array}{c}\begin{array}{c}\text { Standardized } \\
\text { Coefficients }\end{array} \\
\text { Beta }\end{array}$} & \multirow[b]{2}{*}{$t$} & \multirow[b]{2}{*}{ Sig. } & \multicolumn{2}{|c|}{ Collinearity Statistics } \\
\hline & & $\mathrm{B}$ & Std. Error & & & & Tolerance & VIF \\
\hline \multirow[t]{5}{*}{1} & (Constant) &, 020 & 2,352 & & ,008 & ,993 & & \\
\hline & LN_VAR & , 128 &, 065 & ,167 & 1,966 &, 047 & ,931 & 1,074 \\
\hline & LN_LPS &,- 320 & ,073 &,- 490 & $-4,347$ &, 000 &, 527 & 1,898 \\
\hline & LN_DEV &,- 179 &, 062 &,- 382 & $-2,884$ & ,007 & ,381 & 2,622 \\
\hline & LN_MARKT &,- 042 &, 084 &,- 060 &,- 500 & ,620 & ,467 & 2,142 \\
\hline
\end{tabular}

a. Dependent Variable: LN_SPRED

Tabel 4. Uji Non Autokorelasi terhadap Variabel -variabel variance return (X1), market value (X2), dividen (X3) dan laba per saham (X4)

Model Sum m ary
\begin{tabular}{|l|r|r|r|r|c|}
\hline Model & $R$ & R Square & $\begin{array}{c}\text { Adjusted } \\
\text { R Square }\end{array}$ & $\begin{array}{c}\text { Std. Error of } \\
\text { the Estimate }\end{array}$ & $\begin{array}{c}\text { Durbin-W } \\
\text { atson }\end{array}$ \\
\hline 1 &, $875^{\mathrm{a}}$ &, 766 &, 739 &, 33415 & 1,778 \\
\hline
\end{tabular}
a. Predictors: (Constant), LN_MARKT, LN_VAR, LN_LPS, LN_DEV
b. Dependent Variable: LN_SPRED

Dari hasil pengujian Durbin Watson menunjukkan dw 1.778 lebih besar dari batas atas (du) 1.720 dan kurang dari 4-1.739, maka dapat disimpulkan tidak ada korelasi serial diantara disturbance terms, sehingga variabel tersebut independen (tidak ada autokorelasi).

Cara mendeteksi heterokedastisitas adalah dengan melihat grafik scatterplot dan uji Glejsar. Dari hasil uji Glejsar tidak ada satupun variabel independen yang signifikan secara statistik mempengaruhi variabel dependen nilai Absolut Residual. Hal ini terlihat dari probabilitas signifikansi di atas $\alpha=0.05$. Jadi dapat disimpulkan model regresi tidak mengandung adanya heteroskedastisitas.

Tabel 5. Uji Heterokedastisitas terhadap Variabel -variabel variance return (X1), market value (X2), dividen (X3) dan laba per saham (X4)

Coefficients

\begin{tabular}{|rl|r|r|r|r|r|}
\hline \multirow{2}{*}{ Model } & \multicolumn{2}{|c|}{$\begin{array}{c}\text { Unstandardized } \\
\text { Coefficients }\end{array}$} & \multicolumn{2}{c|}{$\begin{array}{c}\text { Standardized } \\
\text { Coefficients }\end{array}$} & \\
\cline { 3 - 4 } & & \multicolumn{1}{|c|}{ B } & Std. Error & \multicolumn{1}{|c|}{ Beta } & \multicolumn{1}{c|}{ S } & \multicolumn{1}{c|}{ Sig. } \\
\hline 1 & (Constant) &,- 281 & 1,060 & &,- 265 &, 792 \\
& LN_VAR &, 047 &, 029 &, 245 & 1,607 &, 117 \\
& LN_LPS &,- 026 &, 033 &,- 159 &,- 784 &, 438 \\
& LN_DEV &, 054 &, 028 &, 461 & 1,933 &, 061 \\
& LN_MARKT &, 021 &, 038 &, 120 &, 556 &, 582 \\
\hline
\end{tabular}

a. Dependent Variable: ABT_UT 
Dalam pengolahan data dengan menggunakan regresi linear, dilakukan beberapa tahapan untuk mencari hubungan antara variabel dependen bid-ask spread (Y) dan variabel independen variance return (X1), market value (X2), dividen (X3), dan laba per saham (X4). Model regresi berdasarkan hasil analisis di atas adalah:

$$
\begin{array}{r}
\mathrm{Y}=.020+.128 \mathrm{X} 1-.320 \mathrm{X} 2-.179 \mathrm{X} 3-.042 \mathrm{X} 4+\mathrm{e} \\
(.047) \quad(0.000)(0.007) \quad(0.620)
\end{array}
$$

Persamaan tersebut menunjukkan angka yang signifikan pada variabel variance return (X1), dividen (X3), dan laba per saham (X4)., namun arah koefisiennya menunjukkan perbedaan yaitu positif dan negatif. Sedangkan market value (X2) tidak signifikan.

\section{Hasil Uji Pengaruh Varian return terhadap bid ask spread}

Berdasarkan tabel 3 dapat diketahui bahwa variabel varian return saham, dengan menggunakan level of significant $\alpha=5 \%$ berpengaruh signifikan terhadap bid-ask spread saham, karena memiliki tingkat signifikansi 0,047 yang lebih kecil dari taraf signifikansi 0,05 . Hasil ini sesuai dengan teori yang menyatakan bahwa volatilitas varian return akan menyebabkan dealer/broker akan menutupinya dengan spread yang tinggi. Variabel varian return saham memiliki koefisien regresi sebesar 0,128. Hasil ini menunjukkan bahwa variabel varian return saham berpengaruh positif dan signifikan terhadap variabel bid-ask spread saham. Sedangkan tanda positif ini menunjukkan apabila varian return naik 1 satuan akan mengakibatkan naiknya bid ask spread sebesar .128 satuan, variabel yang lain dianggap konstan.

Dalam penelitian ini variabel varian return saham mewakili risiko yang dihadapi oleh dealer. Selama periode penelitian dapat diketahui bahwa pergerakan harga saham perusahaan yang masuk dalam Jakarta Islamic Indeks (JII) mengalami pergerakan sehigga menyebabkan dealer berusaha menutupinya dengan spread yang lebih besar. Dengan kata lain, semakin besar risiko suatu saham maka broker/dealer akan berusaha menutupinya dengan spread yang lebih besar. Jadi terdapat hubungan positif antara varian return dengan bid ask spread. Hal ini menunjukkan bahwa hipotesis pertama diterima yang menyatakan varian return saham berpengaruh positif terhadap bid-ask spread saham pada saham 
syariah yang tercatat dalam Jakarta Islamic Indeks (JII) selama periode 20072010.

Hasil penelitian ini konsiten dengan hasil penelitian yang dilakukan oleh Magdalena Nany dan M. Abdul Aris (2003) yang menyatakan bahwa varian return saham berpengaruh positif terhadap bid-ask spread.

\section{Hasil Uji Pengaruh Market Value terhadap bid ask spread}

Koefisien regresi market value yang ditemukan sebesar -.042 dengan tanda negatif. Hal ini berarti setiap kenaikan marker value sebesar 1 satuan akan berdampak pada penurunan bid ask spread sebesar .042 satuan. Jika dilihat dari uji $\mathrm{T}$ diperoleh nilai signifikan $\mathrm{T}$ sebesar 0.620 lebih besar dari alpha 5\% maka hipotesa 2 ditolak yang menyatakan bahwa market value saham berpengaruh negatif terhadap bid-ask spread saham pada saham syariah yang tercatat dalam Jakarta Islamic Indeks (JII) selama periode 2007-2010. Namun secara simultan variabel market value berpengaruh terhadap bid ask spread.

Market value menunjukkan besarnya ukuran perusahaan. Investor menganggap perusahaan besar memiliki risiko lebih kecil dibandingkan dengan perusahaan kecil, karena perusahaan besar dianggap lebih mempunyai akses ke pasar modal (Jogiyanto, 2002). Semakin besar ukuran perusahaan dapat diartikan bahw jumlah aktivitas perdagangan saham juga tinggi diiringgi dengan harga saham yang semakin meningkat. Hal ini menyebabkan sehingga broker/dealer (perantara pedagang efek) tidak perlu memegang saham tersebut terlalu lama sehingga menurunkan biaya pemilikan saham yang berarti mempersempit bid ask spread saham tersebut.

Hasil penelitian ini menolak hipotesa kedua, artinya market value yang tinggi tidak membuat dealer/broker menurunkan biaya kepemilikan, sehingga spread tetap besar. Hal ini dimungkinkan karena harga saham yang tinggi tidak dibarengi dengan volume perdagangan yang tinggi pula. Perlu diingat bahwa market value didapat dari perkalian harga rata-rata saham dengan jumlah saham beredar. Artinya walaupun tidak semua saham beredar aktif diperdagangakan oleh investor karena investor lebih suka untuk memiliki saham tersebut dalam waktu yang lama. Penelitian ini tidak mendukung penelitian yang dilakukan Dwi (2008), Purwanto (2003), Menyah dan Paudyal (1992), Abdul dan Nasuhi (2000). 


\section{Hasil Uji Pengaruh Dividen terhadap bid ask spread}

Koefisien regresi dividen yang ditemukan sebesar .179 dengan tanda negatif. Hal ini berarti setiap kenaikan dividen sebesar 1 satuan akan berdampak pada penurunan bid ask spread investor sebesar .179 satuan. Jika dilihat dari uji T diperoleh nilai signifikan $\mathrm{T}$ sebesar 0.007 lebih kecil dari alpha 5\% maka hipotesa diterima, yang berarti secara statistik dividen mempunyai hubungan dengan bid ask spread saham tetapi arah koefisiennya negatif.

Di dalam penelitian Suharsono (1999) faktor yang paling dominan dan pengambilan keputusan pembelian saham adalah harapan investor mendapat dividen yang memadai. Dalam kaitannya dengan bid ask spread, apabila perusahaan membagikan dividen maka para investor akan tertarik untuk membeli saham perusahaan tersebut sehingga volume perdagangan juga akan ikut naik. Pembagian dividen ini akan menurunkan biaya kepemilikan saham sehingga menurunkan spread. Selain itu pembayaran dividen terkait juga dengan risiko. Bila pembayaran dividen yang dilakukan oleh perusahaan meningkat maka risiko yang ditanggung oleh investor akan menurun. Oleh karena itu, jika pembayaran dividen meningkat, harga saham akan meningkat pula. Ini akan mengurangi risiko perusahaan dan mengakibatkan penurunan bid ask spread. Hasil penelitian ini mendukung penelitian Beaver et al., 1970 dan Rozeff, 1982 (dalam Ryan, 1996) dan menolak penelitian Ratna (2004).

\section{Hasil Uji Pengaruh Laba per Saham terhadap bid ask spread}

Berdasarkan tabel 3 dapat diketahui bahwa variabel laba per saham berpengaruh negatif signifikan dengan tingkat signifikansi 0,000 pada level of significant $\alpha=5 \%$ berpengaruh signifikan terhadap bid-ask spread saham. Variabel laba per saham memiliki koefisien regresi sebesar -.320, artinya apabila laba per saham naik satu satuan maka akan mengakibatkan penurunan bid ask spread sebesar .320 satuan, variabel yang lain dianggap konstan. Hasil ini sesuai dengan teori yang menyatakan bahwa laba per saham akan menyebabkan menurunkan biaya kepemilikan saham sehingga spread akan menurun. Hasil penelitian ini menerima hipotesa ke-4 yang menyatakan bahwa laba per saham mempunyai pengaruh negatif signifikan terhadap ask spread saham syariah yang tercatat dalam Jakarta Islamic Indeks (JII). 
Laba per saham yang tinggi mengindikasikan bahwa perusahaan memiliki prospek yang baik sehingga aktif diperdagangkan di bursa saham. Apabila suatu saham aktif diperdagangkan maka dealer/broker tidak akan lama menyimpan saham tersebut sebelum diperdagangkan. Hal ini akan mengakibatkan menurunnya biaya pemilikan dan pada akhirnya menurunkan tingkat bid ask spread. Hasil penelitian ini didukung oleh hasil penelitian, Nany (2004), Senteney (1991) dalam Callahan dan Carles (1997) yang menunjukkan bahwa spred yang lebih kecil meningkat ketika laba per saham positif daripada ketika laba per saham negatif.

\section{Uji Pengaruh secara Simultan}

Untuk menunjukkan apakah semua variabel independen yang dimasukkan dalam model mempunyai pengaruh signifikan secara bersama-sama terhadap variabel dependen maka digunakan uji F. Berikut ini adalah tabel yang menunjukkan hasil uji $\mathrm{F}$ dan besarnya $\mathrm{F}$ tabel dengan degree of freedom (df) 4 .

Tabel 6. Hasil Pengujian Hipotesis secara Simultan

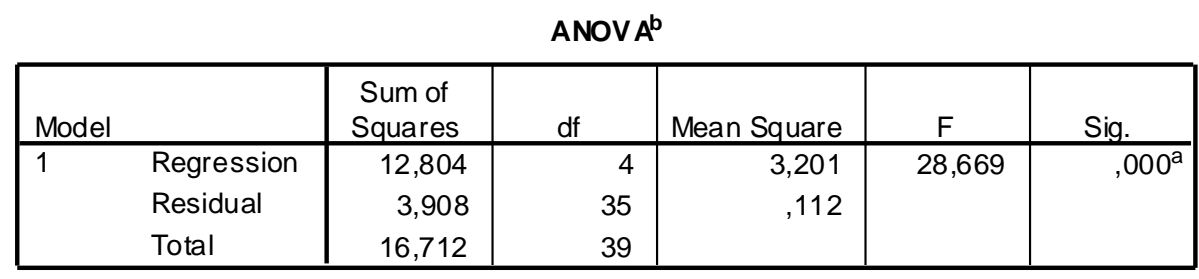

a. Predictors: (Constant), LN_MARKT, LN_VAR, LN_LPS, LN_DEV

b. Dependent Variable: LN_SPRED

Dari tabel 7 di atas diketahui bahwa ada pengaruh secara serentak ditunjukkan dengan besarnya $\mathrm{F}$ hitung sebesar 28.669. Nilai ini lebih besar dari $\mathrm{F}$ tabel $(2.849>2.61)$. Hal ini menunjukkan bahwa terdapat pengaruh yang signifikan dari variabel variance return (X1), market value (X2), dividen (X3), dan laba per saham (X4) terhadap bid ask spread (Y). Dengan demikian pengujian menunjukkan $\mathrm{H} 1$ diterima.

\section{Interpretasi Koefisien Determinasi}

Koefisien determinasi digunakan untuk mengukur proporsi total variasi dependen variabel yang dijelaskan oleh independen variabel. Jika nilai koefisien 
determinasi (R Square) semakin mendekati angka 1, maka variabel independen secara bersama-sama mempunyai pengaruh yang kuat dalam menjelaskan variabel dependen.Sedangkan bila R Square mendekati 0 maka variabel independen semakin lemah dalam menjelaskan pengaruhya terhadap variabel dependen.

Dari hasil analisis regresi diperoleh nilai adjusted R Square sebesar 73.9\% yang berarti secara bersama-sama variabel bebas (varian return, market value, dividen dan laba per saham dan Devidend Pay Out Ratio) mampu menjelaskan variabel terikat (bid ask spread) sebesar $73.9 \%$ sedangkan sisanya sebesar $26.1 \%$ dijelaskan oleh variabel lain di luar persamaan model. Berdasarkan uji F diperoleh nilai signifikan $\mathrm{F}$ sebesar 0,000 lebih kecil dari alpha 5\%. Sehingga secara statistik variabel independen dapat menjelaskan variabel dependen sebesar $73.9 \%$ dan signifikan pada taraf $5 \%$.

\section{KESIMPULAN}

Besar kecilnya bid ask spread saham ditentukan oleh beberapa faktor antara lain varian return, market value, deviden dan laba per saham. Pada perusahaan sampel penelitian yaitu saham biasa untuk perusahaan go public yang tercatat dalam JII pada tahun 2007-2010, secara bersama-sama (simultan) variabel independen (varian return, market value, deviden dan laba per saham ) berpengaruh terhadap variabel dependen (bid ask spread). Adapun secara parsial, faktor yang berpengaruh signifikan terhadap bid ask spread adalah varian return, deviden dan laba per saham sedangkan market value tidak signifikan. Varian return berpengaruh positif signifikan terhadap bid ask spread artinya volatilitas varian return akan menyebabkan dealer/broker akan menutupinya dengan spread yang tinggi. Dividen dan laba per saham berpengaruh negatif signfikan terhadap bid ask spread. Apabila pembayaran dividen yang dilakukan oleh perusahaan meningkat maka risiko yang ditanggung oleh investor akan menurun dampaknya risiko yang ditanggung perusahaan berkurang mengakibatkan penurunan bid ask spread. Apabila suatu saham aktif diperdagangkan maka dealer/broker tidak akan lama menyimpan saham tersebut sebelum diperdagangkan. Hal ini akan mengakibatkan menurunnya biaya pemilikan dan pada akhirnya menurunkan tingkat bid ask spread. Secara parsial market value tidak berpengaruh terhadap 
bid ask spread dimungkinkan karena kenaikan harga saham tidak dibarengi dengan meningkatnya jumlah saham yang diperdagangkan.

\section{DAFTAR PUSTAKA}

Abdul dan Nasuhi Hidayat. 2000. "Studi Empiris Tentang Pengaruh Volume Perdagangan Dan Return Terhadap Bid-Ask Spread Industri Rokok Di Bursa Efek Jakarta Dengan Model Koreksi Kesalahan”. Jurnal Riset Akuntansi Indonesia. Vol.3 No.1, Januari, Hal 69-85.

Akhigbe, Aigbe dan Jeff Madura. 1996. Dividend policy and Corporate Performance. Journal of Bisiness Finance and Accounting, 23, Desember, 1267-1287.

Atkins, Allens B. dan Edward A Dyl. 1990. Price reverals, bid-ask spread and market efficiency. Journal of Financial Quantitative Analysis, 25, 535547.

1997. Market structure and rerted trading volume: Nasdaq versus the NYSE. Journal of Finance Research, Vol. XX, No. 3, p. 291304.

1997. Transaction cost and holding period for common stock. Journal of Finance. Vol. III, No. 1, p. 309-320.

Callahan, CarolynM., Charles MC Lee, dan Teri Lombardi Yohn. 1997. Accounting Infoermation and Bid Ask Spreads. Accounting Horizons, Vol. 11 No.4.

Corrado, Charles J., Bradford P.Jordan. 2000. Fundamentals of Invesment: Valuation and Management. The Irwin/McGraw-Hill.

Dwi, Sri. 2008. Pengaruh Return Saham, Volume Perdagangan Saham dan Varian Return Saham terhadap Bid-Ask Spread Saham pada Perusahaan Manufaktur yang Tergabung dalam Indeks Lq 45 Periode tahun 20032005. Jurnal Siasat Bisnis, Vol. 12 No. 1, April 2008 Hal: 27 - 38.

Fabozzi, Frank J. 2000. Manajemen Investasi, Terjemahan, Jilid 1, 2. Jakarta: Penerbit Salemba Empat.

Hamilton, James L. 1976. Competition, scale economics and transaction cost in the stock market. Journal of Financial Quantitative Analysis, No. 9, p. 779-802.

Jogiyanto. 2002. Teori Portofolio dan Analisis Investasi. Yogyakarta: BPFE.

Jones, C.P. 2002. Investment: Analysis and Management, $7^{\text {th }}$ edition. New York: John Wiley and Sons, Inc.

Krinsky, Itzhak dan Jason Lee. 1996. "Earning Announcements and the Components of the Bid-Ask Spread". The Journal of Finance, Vol.LI, No.4, September, pp.1523-1535 
Magdalena Nany dan M. Abdul Aris. 2004. "Pengujian Stabilitas Struktural Pengaruh Harga Saham, Return Saham, Varian Return Saham Dan Volume Perdagangan Terhadap Bid-Ask Spread Pra Dan Pasca Laporan Keuangan", Empirika. Vol.17 No.1, Hal 40-49.

Magdalena Nany dan M. Abdul Aris. 2004. "Pengujian Stabilitas Struktural Pengaruh Harga Saham, Return Saham, Varian Return Saham dan Volume Perdagangan Terhadap Bid-Ask Spread Pra dan Pasca Laporan Keuangan", Empirika. Vol.17 No.1, Hal 40-49.

Maulina, Venus. 2010. Asymmetric Information Cost Dan Holding Periods Saham Biasa Di Bursa Efek Indonesia. Jurnal Iqtishoduna Vol.6 No.3 Tahun 2010.

Menyah, K dan Kristibna Paudyal, 1996. The Determinants and Dynamics of Bid Ask Spreads on The London Stock Exchange. The Journal of Financial Research, Vol. XIX No. 3

Miller, Merton H. dan Kevin Rock. 1985. Dividend policy under asymmetry information. Journal of Finance, 40, September, 1031-51.

Purwanto, Agus. 2003. Pengaruh Harga Saham, Volume Perdagangan, dan Varian Return Terhadap Bid-Ask Spread Pada Masa Sebelum dan Sesudah Right Issue di Bursa Efek Jakarta Periode 2000-2002. Universitan Diponegoro Semarang.

Ratna, Anita. 2004. Analisis faktor-faktor yang Mempengaruhi Bid Ask Spread. Thesis. Universitas Diponegoro Semarang.

Ryan, Huldah. 1996. The Use of Financial Ratios As Measures of Risk in the Determination of The Bid Ask Spread. Journal of Financial and Strategis Decisions, Vol. 9 No.2.

Sawidji Widyoatmojo. 2005. Cara Sehat Investasi di Pasar Modal: Penge-tahuan Dasar. Jakarta: Penerbit Elex Multimedia.

Sharpe, William. Gordon J.Alexander. Jeffry V. baily. 2005. Investasi. PT. Indeks.

Stoll, Hans R.1989. Inferring The Components of Bid Ask Spread: Theory and Empirical Test. The Journal of Finance, Vo. XLIV. No.1 March.

Sugiyono. 2002. Metode Penelitian Bisnis. Bandung: Penerbit CV. Alfabeta.

Suharsono, Judi. 1999. Pengaruh kualitas informasi pasar modal terhadap keputusan pembelian saham di kalangan investor lokal pada Galery bursa di Kotamadya Malang, Tesis, Program Pasca Sarjana Universitas Brawijaya, Malang. 
